\title{
Evaluación del conocimiento de los ganaderos sobre la tuberculosis bovina e implicaciones para su control
}

\section{Cattle producer knowledge toward bovine tuberculosis and implications to its control}

\author{
Juan García Díeza, Ana Claudia Coelhob
}

\begin{abstract}
RESUMEN
Durante los meses de abril a julio de 2012, se entrevistaron a 154 ganaderos del norte de Portugal con el objetivo de evaluar su conocimiento sobre la tuberculosis bovina (TBb). De acuerdo con los resultados, $14.3 \%$ de los ganaderos declararon haber tenido, al menos una vez, el hato infectado con TBb. Además, estos mostraron que los ganaderos poseen un buen conocimiento de la enfermedad a pesar de la elevada edad y de la baja escolaridad/formación. Sin embargo, los resultados mostraron que el $\mathbf{2 7 . 9} \%$ de los ganaderos desconoce las pérdidas económicas asociadas a las restricciones comerciales causadas por la TBb. El $25 \%$ desconoce que la transmisión principal de la TBb es por vía aerógena, de la misma forma que el $\mathbf{4 6 . 7} \%$ también desconoce que la fauna salvaje puede actuar como reservorio de la enfermedad. El grado de conocimiento de los ganaderos sobre la TBb puede ser de gran importancia para aumentar la eficacia del programa nacional de erradicación de la TBb. Los resultados obtenidos deben ser tomados en consideración por parte de las autoridades veterinarias en la elaboración de medidas de control de la enfermedad, con el objetivo de garantizar su eficacia y correcta implementación.
\end{abstract}

PALABRAS CLAVE: Tuberculosis, Bovinos, Bioseguridad, Formación, Ganaderos.

\begin{abstract}
A cross sectional study was conducted between April and July 2012 in the North of Portugal, to evaluates cattle owners' knowledge regarding bovine tuberculosis. A questionnaire was provided to 154 cattle owners. According to the survey, $\mathbf{1 4 . 3} \%$ of respondents had its herd already infected by tuberculosis. Result showed that farmers have a good knowledge on the disease despite age and/ or lack of training. However, $27.9 \%$ not recognized bovine tuberculosis as one of the most important diseases of cattle due to the economical losses and trade restrictions, $25 \%$ not recognized the airborne transmission and $46.7 \%$ unknown wildlife as a reservoir of bovine tuberculosis. Farmer knowledge about bovine tuberculosis can be considered as an important tool to improve official erradication plans. The present results could be useful for policy makers when planning mitigation measures to consider knowledge levels by cattle owners for effective implementation.
\end{abstract}

KEY WORDS: Tuberculosis, Cattle, Biosecurity, Education, Farmers.

\section{INTRODUCCIÓN}

La tuberculosis bovina (TBb) es una enfermedad reemergente de carácter zoonótico causada por Mycobacterium bovis. Esta bacteria pertenece al denominado complejo Mycobacterium

\section{INTRODUCTION}

Bovine tuberculosis (BTb) is an important reemerging zoonotic disease caused by Mycobacterium bovis, a member of the Mycobacterium tuberculosis complex (MTC) that

Recibido el 11 de junio de 2013. Aceptado el 20 de julio de 2013.

a Cooperativa Agrícola de Chaves. ADS Vila Pouca de Aguiar. Bairro da Brangada. 5450-005. Vila Pouca de Aguiar, Portugal. Tel. +351-259417782. Fax: +351259417376. juangarciadiez@gmail.com. Correspondencia al primer autor.

b Departamento das Ciências Veterinárias, CECAV, Universidade de Trás-os-Montes e Alto Douro, Vila Real, Portugal. 
tuberculosis, el cual afecta tanto a animales domésticos como salvajes. Su distribución mundial es causa de cuantiosas pérdidas económicas debido a las restricciones comerciales de animales y sus productos(1).

La TBb presenta una cierta importancia en la Península Ibérica(2) donde se ha demostrado que su control es de elevada dificultad. En los últimos años se ha prestado una mayor atención en la aplicación de medidas preventivas de reproducción, así como de bioseguridad en la explotación ganadera, con el objetivo de reducir la infeccion(3). Estudios recientes sugieren que el éxito de la aplicación de estas medidas está directamente relacionado con el grado de conocimiento de los ganaderos. La falta de conocimiento y formación adecuada sobre la TBb afecta no sólo el bienestar de los bovinos, sino que mantiene la propagación de la enfermedad en la población $(4,5)$.

El impacto de la tuberculosis en la salud humana es muy elevado, estimándose que más de 3.5 millones de personas fallecen anualmente por esta enfermedad(6), siendo que los casos de tuberculosis zoonótica son referidos principalmente en los países en vías de desarrollo(7). Del total de los casos de tuberculosis humana, Mycobacterium bovis es responsable entre 1 y $14 \%$ del total de los casos, aunque en paises en vías de desarrollo, las tasas de infección son todavía mayores(6-10).

Es importante que los ganaderos tengan una formación y conocimientos mínimos para entender los riesgos y las posibles vías de transmisión de los animales a las personas $(5,6)$. Así, dado que el grado de conocimiento sobre la tuberculosis bovina que presentan los ganaderos en Portugal es desconocido, el objetivo de este estudio consitió en verificar dicho conocimiento en los ganaderos del nordeste del Portugal.

\section{MATERIALES Y MÉTODOS}

Diseño del estudio

Los ganaderos y los hatos incluidos en este estudio se encuentran localizados en tres affects both domestic and wild animals worldwide causing major economic losses and constraining international trade of animals and their products(1).

$\mathrm{BTb}$ is a serious disease of cattle in Iberian Peninsula(2). The disease has proven difficult to control in the cattle population. In recent years, there has been growing interest in the potential to employ both husbandry and biosecurity practices to reduce the infection(3). Previous studies suggest that control measures largely depend on the knowledge of cattle owners who play a critical role in the implementation and success of disease programs. Lack of knowledge about tuberculosis could affect the healthseeking behavior and sustain the transmission of the disease within the community $(4,5)$.

The impact of tuberculosis on human health is very high with more than 3.5 million people dying annually from tuberculosis(6) and most of the cases of zoonotical transmission have been reported in developed countries(7). From the total cases of human tuberculosis cases, Mycobacterium bovis is the responsible for a range from 1 to $14 \%$, although higher rates has been described in development countries $(6-10)$. It becomes important for cattle owners to acquire a degree of knowledge to understand the risks and possible transmission routes to humans $(5,6)$. Due to the level of knowledge of bovine tuberculosis by Portuguese cattle owners is unknown, the aim of this study was to assess and determine cattle owners' knowledge of bovine tuberculosis in the northeast of Portugal.

\section{MATERIAL AND METHODS}

Study design

Bovine owners and herds included in this study were located in three counties from the region of Trás-os-Montes e Alto Douro, Northeast of Portugal. The survey was carried out between April to July 2012 in 154 cattle herds.

A list was obtained of all cattle herds surveyed of tuberculosis according to the national 
municipios de la región de Tras-os-Montes e Alto Douro (nordeste de Portugal). Las encuestas se realizaron entre los meses de abril a julio de 2012 en 154 explotaciones bovinas.

La lista de las explotaciones ganaderas se obtuvo a partir de los registros de las explotaciones rastreadas para la TBb de acuerdo con el plano nacional de erradicación de la TBb en el nordeste de Portugal del año 2012. De acuerdo con los datos del progama nacional de sanidad animal del Ministerio de Agricultura (Pisa.net), un total de 7,676 cabezas fueron rastreadas para detectar la infeccion por Mycobacterium bovis en dicha area. Según los datos oficiales, la prevalencia de TBb fue de 0.37 y $0.33 \%$ en los años 2010 y 2011 respectivamente. Para ser consideradas dentro del estudio, todas las explotaciones bovinas debían tener al menos un bovino, así como el acuerdo de los ganaderos en participar en este estudio. La selección de las explotaciones ganaderas para el estudio se obtuvo de forma aleatoria, siendo que el tamaño de muestra se calculó con el programa informático WinEpiscope 2.0.

\section{Obtención de los datos}

Todas las explotaciones ganaderas del estudio se visitaron. La información relativa al conocimiento de la TBb así como la caracterizacion de las granjas se obtuvo con un cuestionario distribuido a los ganaderos durante la realización de la entrevista. Todas las preguntas del cuestionario fueron leidas a los ganaderos, y eran tanto de respuesta simple como de respuesta múltiple, con un tiempo de 20 min para responder a todas las preguntas. El cuestionario se elaboró y tradujo al portugués. Para evaluar el correcto diseño del cuestionario, éste fue probado con 25 ganaderos de otras áreas que no fueron incluidos en el estudio. Todos los cuestionarios se administraron a los ganaderos entre abril y julio de 2012.

Todas las preguntas del cuestionario se elaboraron a partir de revisión bibliográfica sobre eradication program of bovine tuberculosis in the Northeast Portugal assessed in 2012. According to data from the National Animal Health Software of the Ministry of Agriculture (PISA.net), a total of 7,676 head were tested for Mycobacterium bovis infection in the study area in that year. According to the official data, BTb prevalence was $0.37 \%$ and $0.33 \%$ in 2010 and 2011 respectively. To be considered eligible for the study, all herds' participants were required to be 1 or more head and owners agree with the study protocol. A random list of numbers was generated of each eligible herd. Sample size was calculated using the programme WinEpiscope 2.0.

\section{Data collection}

All herds were visited and information on knowledge and general information about the farms and farmers was obtained using a questionnaire (available in Portuguese upon request). The questionnaire was administered to farmers or managers on all farms by personal interview in Portuguese. During the interview, the questions were read out to the farmer by the interviewer and answers were selected from multiple close questions or otherwise written down, that take along $20 \mathrm{~min}$. The questionnaire was designed and was translated into Portuguese. To evaluate the design of the questionnaire it was pre-tested with 25 cattle producers from the other areas that were not included in the study. Questionnaires were administered between April to July 2012.

All questions were related to variables derived from a literature review of knowledge for bovine tuberculosis in ruminants. The questionnaire included 36 questions. To keep it simple, the most questions $32(88.9 \%)$ were closed (answers limited to "yes", "no" and "sometimes/ maybe"). All such questions were pre-coded (0/1 - including "sometimes/maybe" in 0). Two questions were semi-closed (including information on number of animals and locations). Two questions were open. All data from the questionnaires were entered into SPSS 19.0 software (SPSS Inc., Chicago), carefully 
el conocimiento de la tuberculosis bovina en rumiantes. El cuestionario estaba formado por 36 preguntas. Para facilitar las respuestas de los ganaderos, la mayoria de las preguntas (32; $88.9 \%$ ) eran del tipo "si/no" y "a veces". Todas las preguntas se codificaron $(0 / 1$, siendo la respuesta "a veces" codificada como 0 ).

Dos preguntas eran de respuesta escrita simple (localización de la granja y el número de animales). Dos preguntas eran de respuesta abierta. Todos los datos obtenidos a partir de los cuestionarios fueron introducidos en el software SPSS 19.0 (SPSS I nc. Chicago). Todos los datos se revisaron cuidadosamente, siendo los errores inmediatamente corregidos.

Toda la informacion obtenida se clasificó en tres partes: características del hato como el tamaño, raza, tipo de producción (leche o carne), localización (proximidad con otras explotaciones); manejo de los animales y de la granja; conocimiento sobre la tuberculosis bovina, incluyendo en esta parte las características socio demográficas de los ganaderos como la edad, escolaridad o profesión.

El conocimiento sobre la tuberculosis bovina se evaluó a partir de 21 preguntas. La respuesta a cada pregunta se utilizó para crear una puntuación de 0 a 21 . El valor obtenido se sometió a análisis descriptivo y al análisis de la curva de distribución para verificar la normalidad. Posteriormente, se analizó la distribución de las puntuaciones entre grupos mediante la t de Student. Una vez normalizadas las puntuaciones, éstas fueron dicotomizadas utilizando un valor medio, donde los valores por encima de la media fueron codificados como 1 indicando un elevado conocimiento. El valor de 1 fue atribuido a las preguntas correctamente respondidas, 0 en el caso de las preguntas mal respondidas o en blanco. De esta forma, el valor medio de corte obtenido fue de 13.02, donde las respuestas fueron clasificadas como de elevado conocimiento (puntuación superior al valor de corte) o de bajo conocimiento (puntuación inferior al valor de corte). checked and errors were corrected and immediately usable as SPSS data set. All recorded information from each herd was carefully compared with the paper questionnaire, checked and typing errors were detected and corrected. Information collected in the survey was classified into three sections: variables concerning herd characteristics, such as size of herd, breed, type of production (milk or meat), location (proximity to other farms); farming and management; farmers knowledge about bovine tuberculosis variables concerning the farmer socio-demographic composition, such as age, educational level, major occupation.

Overall knowledge of the study participants about bovine tuberculosis was assessed using 21 main questions. Response to those questions was added together to generated knowledge score ranging from 0 to 21 . The scores obtained were submitted to a descriptive analysis and analysis of the distribution curve, in order to check the normality. Afterwards, we checked the distribution of the scores between the groups by the t test. After assessing normality to the score using a normal distribution curve, the composite score was dichotomized using mean as a cut-off value so that higher value coded as 1 showing higher overall knowledge. A score of one was given to correct responses, zero being used for incorrect/do not know responses. Based on the mean score of the composite variable (mean $=13.02$ ), the responses were categorised into high (score above mean value) and low (score below mean value).

\section{Data analysis}

Chi-squared $\left(X^{2}\right)$ tests were used to compare variables. Analyses were done with SPSS 19.0 software (SPSS Inc., Chicago) for Windows considering a probability $(p)$ of less than 0.05 as statistically significant.

\section{RESULTS}

Farmer socio-demographic composition

A total of 154 cattle farmers were personally 
Análisis de los datos

La comparación de las variables se efectuó mediante la utilización de la Chi-cuadrada $\left(X^{2}\right)$. Todos los tratamientos estatísticos fueron efectuados con recurso al programa informático SPSS 19.0 (SPSS Inc., Chicago) para Windows considerando como significativo un valor $\mathrm{P}<0.05$.

\section{RESULTADOS}

Características sociodemográficas de los ganaderos

Se entrevistó a un total de 154 ganaderos (Cuadro 1). La muestra estaba formada por 132 hombres, (85.7\%) y 22 mujeres (14.3 $\%)$. Todos los entrevistados vivan en el mismo lugar de la explotación ganadera y tenian una media de 51 años ( $74 \%$ ), donde el manejo de los animales y las operaciones en la explotación era efectuado conjuntamente por hombres y mujeres $(63.6 \%)$. Un $71.4 \%$ de los encuestados tenía la escolaridad obligatoria mientras que sólo un $2.6 \%$ poseía estudios superiores o formación específica. interviewed (Table 1). The sample consisted of 132 men $(85.7 \%)$ and 22 women (14.3\%). All the respondents lived at the farm location and averaged over 51 years old (74\%). Both women and men working together (63.6\%) generally operate farms. The level of educational achievement revealed $71.4 \%$ having only primary education and $2.6 \%$ having high school or technical training.

Farm characterization

The results of farm characterization (Table 1 ) revealed the main animal production was meat (94.2 \%) based on Maronesa, a local breed ( $71 \%$ ) that afforded Carne Maronesa (Maronesa beef), a protected geographical indication. The majority of the respondent (57.8\%) had three or less head indicating the small-size and familymanagement of the farms of the study according to the distribution of the herd size. The average herd size was 4 head. However, 18.8, 22.1 and $16.9 \%$ of the herds studied presented 3, 2 or 1 head respectively. Only $10 \%$ of respondent had over 10 head (range 10 to 30).

Cuadro 1. Caracteríticas sociodemográficas de los ganaderos y caracterización de las explotaciones ganaderas

Table 1. Socio-demographic characteristic and farm characterization of the respondent

\begin{tabular}{|c|c|c|c|c|c|}
\hline & $\mathrm{N}$ & $\%$ & & $\mathrm{~N}$ & $\%$ \\
\hline Gender: & & & Main animal production: & & \\
\hline Male & 132 & 85.7 & Meat & 145 & 94.2 \\
\hline \multirow[t]{2}{*}{ Female } & 22 & 14.3 & Milk & 3 & 1.9 \\
\hline & & & Both & 6 & 3.9 \\
\hline \multicolumn{3}{|l|}{ Animal and farm operations: } & \multicolumn{3}{|c|}{ Presence of others farm animals: } \\
\hline Male & 34 & 22.1 & Sheep & 11 & 7.1 \\
\hline Female & 22 & 14.3 & Goat & 14 & 9.1 \\
\hline \multirow[t]{3}{*}{ Both } & 98 & 63.6 & Swine & 7 & 4.5 \\
\hline & & & Chicken & 45 & 29.2 \\
\hline & & & Rabbit & 24 & 15.6 \\
\hline Age: & & & Herd sanitary status: & & \\
\hline$<30$ & 4 & 2.6 & Known & 27 & 17.5 \\
\hline $31-50$ & 36 & 23.4 & Unknown & 127 & 82.5 \\
\hline$>51$ & 114 & 74.0 & & & \\
\hline Level of education: & & & Veterinary assistance: & & \\
\hline Primary school & 110 & 71.4 & Yes & 61 & 39.6 \\
\hline High school or technical training & 4 & 2.6 & No & 93 & 60.4 \\
\hline
\end{tabular}


Caracterización delas explotaciones ganaderas Los resultados muestran (Cuadro 1) que $94.2 \%$ de las explotaciones en estudio son de vacuno de carne de raza Maronesa (raza autóctona) ( $71 \%$ ), para la producción de Carne Maronesa, la cual posee la distinción de Indicación Geográfica Protegida. La mayoria de los encuestados (57.8\%) posee 3 o menos cabezas por explotación, lo que indica el reducido tamaño de las mismas así como su gestión/ manejo familiar.

Si bien el tamaño medio de cada rebaño es de 4 cabezas, se observó que $18.8,22.1$ y $16.9 \%$ de las explotaciones en estudio poseían 3, 2 ó 1 cabeza(s) respectivamente. Sólo $10 \%$ poseía más de 10 cabezas (rango entre 10 a 30). La presencia de otras especies animales de interés ganadero en la misma explotacióon bovina fueron ovejas ( $7.1 \%)$, cabras (9.1\%), cerdos $(4.5 \%)$, gallinas (29.2\%) y conejos (15.6 $\%)$. El estudio del manejo veterinario reveló que $82.5 \%$ de los ganaderos desconoce la clasificación sanitaria oficial de su explotación (relativamente a la tuberculosis y brucelosis bovina), $60.4 \%$ carece de apoyo/asesoramiento veterinario y $69.5 \%$ sólo requirió la presencia de un veterinario en caso de necesidad.

Conocimiento general sobre la tuberculosis bovina

Según los resultados del cuestionario (Cuadro 2), el $14.3 \%$ de los encuestados declaró haber tenido su hato infectado por tuberculosis al menos una vez. El tamaño medio de los hatos infectados fue de cinco cabezas, aunque según las respuestas de los ganaderos, ninguna explotación lechera fue positiva. El $4 \%$ de los ganaderos declaró haber padecido de tuberculosis mientras que un $13 \%$ declaró tener conocimiento de amigos o familiares con tuberculosis.

Además, la relación existente en hatos positivos y el conocimiento de amigos y familiares con tuberculosis fue significativo $(\mathrm{P}<0.01)$. Todavía, 73.4 \% reconoció las características zoonóticas
The presence of another farm animals commingling with cattle were sheep $(7.1 \%)$, goats $(9.1 \%)$, swine $(4.5 \%)$, chicken $(29.2 \%)$ and rabbits (15.6\%). The study of the veterinary farm management revealed that $82.5 \%$ of the respondents answered no knowledge about their official herd sanitary status (regarding tuberculosis and brucellosis), $60.4 \%$ had not veterinary technical support and $69.5 \%$ of respondents requested veterinary services only when necessary.

General knowledge about bovine tuberculosis According to the survey (Table 2), $14.3 \%$ of respondents had its herd already infected by tuberculosis (one time at least). The average size of infected herds was five heads and according to the respondents, any dairy has been infected by BTb. Four percentage of the farmers had suffered tuberculosis and $13 \%$ of them answered that knew a family member or a friend with tuberculosis.

In addition, an association between infected herd and family member or friends infected was statistically significant $(P<0.01)$. Furthermore, zoonotic characteristic of this disease was indicated by $73.4 \%$ of respondent.

Bovine tuberculosis is an infectious disease that affects the respiratory tract as recognized by $72.1 \%$ of respondent, however $52.6 \%$ recognized that tuberculosis can also affects the digestive tract.

Questions about routes of transmission revealed that cattle-to-cattle transmission was answered by $77.9 \%$ of respondent, $76.1 \%$ associated the inhalation of aerosols as the main route of transmission although $62.3 \%$ and $73.4 \%$ associated grazing and milking of infected dams as routes of infection respectively. Indeed, $54.5 \%$ answered that deer or wild boar may be a source of tuberculosis for their livestock. Tuberculosis transmission due to contact with infected ones, trough grazing and by possible contact with wild animals was statistically 
de la TBb. El $72.1 \%$ de los ganaderos reconoció que la $\mathrm{TBb}$ es una enfermedad infecciosa que afecta al tracto respiratorio, mientras que un 52.6 \% sabía que tambien podía afectar al tracto digestivo.

Las preguntas relativas a las vías de transmisión indicaron que la infección de animal para animal fue corectamente respondida por el $77.9 \%$, el $76.1 \%$ indicó que la infección por vía aerogénica es la vía principal de transmisión, mientras que el $62.3 \%$ y el $73.4 \%$ de los ganaderos también indicaron correctamente la posible infección a través del pasto y del amantado respectivamente. Además, el $54.5 \%$ respondió que la fauna salvaje, como los venados o los jabalíes pueden actuar como fuentes de infección del ganado. La transmisión de la tuberculosis a través del contacto con animales infectados, a través del pasto $(P<0.01)$ o por contacto con animales salvajes $(P<0.001)$ fue significativa en hatos en que los ganaderos declararon haber estado infectados.

La evaluación del conocimiento de la sintomatología clínica mostró que el 59.1 \% consideró que los animales infectados presentan síntomas evidentes y además, el $45.5 \%$ consideró que esta sintomatología aparece rápidamente. Esta última característica fue estatísticamente significativa en aquellos hatos que ya fueron positivos a la TBb $(\mathrm{P}<0.01)$ así como en aquellos ganaderos que tuvieron conocimiento de amigos y familiares infectados $(P<0.05)$.

El diagnóstico de la TBb mediante la prueba de intradermotuberculinización comparada, de acuerdo con las normas del programa nacional de erradicación de la tuberculosis bovina, se reconoció por casi un $70 \%$ de los ganaderos. Sin embargo, el diagnóstico de la misma por medio del análisis sanguíneo o por la inspección sanitaria en mataderos fue reconocida por 72.7 y $37 \%$ respectivamente.

El diagnóstico de la TBb mediante la prueba del interferón gamma fue estatísticamente
Cuadro 2. Exposición de variables para el estudio del conocimiento de la tuberculosis bovina (TBb)

Table 2. Exposure variables to study overall knowledge about bovine tuberculosis

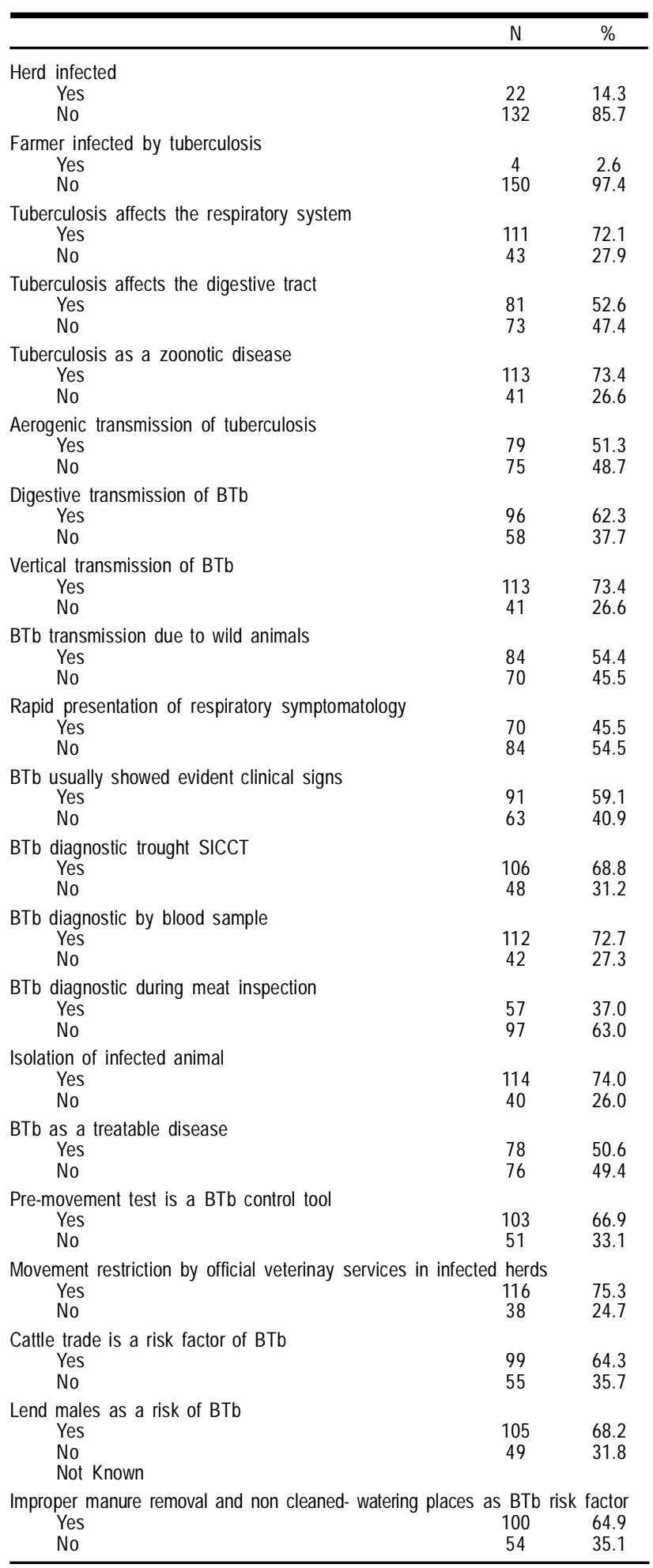


significativa en aquellos ganaderos que tuvieron conocimiento de amigos y familiares enfermos con tuberculosis $(P<0.05)$. Además, el $66.9 \%$ respondió que los test pre-movimiento servían para su diagnóstico. Relativamente al manejo de los bovinos infectados, $74 \%$ de los ganaderos consideró que el aislamiento del resto del hato era una medida adecuada, así como el $75.3 \%$ reconoció la prohibición legal de entradas y salidas de bovinos en la explotación. Aunque la erradicación de la TBb se basa en el diagnóstico y sacrificio obligatorio de los positivos, $50 \%$ de los ganaderos considera que la TBb es una enfermedad tratable, siendo esta respuesta significativa $(P<0.001)$ entre aquellos ganaderos que declararon conocer amigos y familiares infectados.

Por último, los ganaderos consideraron que el comercio de ganado (64.3\%), la utilización de toros para monta natural (68.8\%), la utilización de agua de bebida no tratada, así como la presencia de camas sucias (64.9\%) son factores de riesgo de infección por tuberculosis.

\section{DISCUSION}

La TBb es una enfermedad crónica causada por Mycobacterium bovis cuya importancia se debe a sus repercusiones tanto económicas como sanitarias. Aunque existen diversas medidas de control como programas de erradicación, inspección sanitaria, vigilancia epidemiológica, tratamiento térmico de la leche o vacunación en personas con BCG, se continúa la declaración de casos de tuberculosis zoonótica; por lo que todavía esta enfermedad es considerada como un riesgo para la salud pública. Si bien, el control de la TBb se debe principalmente a las implicaciones comerciales que la enfermedad conlleva(1).

En Portugal, según los datos oficiales de la TBb, la prevalencia animal aumentó de 0.22 a $0.91 \%$ en animales, mientras que la prevalencia en hato aumentó de un 0.07 a $0.26 \%$ entre los años 2005 y 2010(11). significant $(P<0.01, \quad P<0.05, \quad P<0.001$ respectively) in infected herd.

Investigation of clinical signs showed that $59.1 \%$ of respondent considered that symptomatology in infected animal is evident and $45.5 \%$ of them answered that respiratory signs appear quickly. This fact was statistically significant in respondent that had already infected herd $(P<0.01)$ and in case of family members or friends infected $(P<0.05)$.

Diagnosis of bovine tuberculosis by the single intradermal comparative cervical tuberculin test (SICCT) according to the national eradication program of bovine tuberculosis, was recognized by almost $70 \%$. However, tuberculosis diagnosis by blood sample analysis or associated to meat inspection at slaughterhouse was recognized by 72.7 and $37 \%$ respectively.

Diagnosis of bovine tuberculosis by blood sample analysis through interferon gamma assay was statistically significant in case of family member or friends infected $(P<0.05)$. In addition, $66.9 \%$ of respondent recognized the pre-movement as a bovine tuberculosis diagnostic test.

The study of infected animal management reported that $74 \%$ of respondent consider isolation of those positives as a correct practice and $75.3 \%$ know that cattle movement is restricted by law in infected herd. Although, eradication program of bovine tuberculosis is based on test-and slaughter of those positive, half of respondent considered tuberculosis as a treatable disease. Our study revealed an association between the knowledge of family members or friend infected and tuberculosis as a treatable disease $(P<0.001)$.

Farmers consider cattle trade $(64.3 \%)$ and loaned bulls $(68.8 \%)$ as a high risk practice of tuberculosis infection. In addition, untreated water for animal consumption and dirty bed was also recognized by $64.9 \%$. 
El control de la TBb en Portugal es obligatorio por ley. Este se basa en el diagnóstico y sacrificio obligatorio de los bovinos positivos(12), así como en restricciones a las entradas y salidas de ganado en las explotaciones no indemnes.

Sin embargo, el aumento de la prevalencia animal como de la prevalencia en hato, muestra la necesidad de desarrollar nuevas estrategias complementarias a las medidas sanitarias existentes. La formación de los ganaderos puede ser fundamental para aumentar la eficacia del plano nacional de erradicación de la TBb, disminuyendo la prevalencia y su posterior erradicación. Las agrupaciones de defensa sanitaria ganadera juegan un papel esencial en la aplicación y ejecución del plan nacional de erradicación, en la formación y asesoramiento de los ganaderos. Aunque los casos de tuberculosis en personas en el noreste de Portugal disminuyeron en los últimos años(13), no hay datos oficiales de casos de tuberculosis entre los ganaderos(14).

De acuerdo con los resultados de nuestro estudio, casi el $75 \%$ de los ganaderos tienen una media de 51 años y una escasa formación y escolaridad. Si bien estos aspectos no influenciaron el conocimiento de las características más importantes de la TBb como la sintomatología clínica, las vías de transmisión o su importancia zoonótica.

La transmisión de la TBb entre animales se produce normalmente por vía aerógena(1). Así, $77.9 \%$ de los ganaderos reconoce la trasmisión directa de bovino a bovino, siendo que el $76.1 \%$ de los mismos sabe que la infección por vía aerógena, afecta principalmente la parte pulmonar(15).

Aunque la infección por vía digestiva es considerada como secundaria(16), el estudio muestra que los ganaderos tienen conocimiento de la misma. Así, el 62.3 y $73.4 \%$ de los ganaderos reconoció que el pasto y el amamantamiento son posibles rutas de infección gastrointestinal, respectivamente. Si bien la

\section{DISCUSSION}

Bovine tuberculosis (BTb) is a chronic disease caused by Mycobacterium bovis that remains a major, costly infectious disease of cattle. Despite its control by herd testing, meat inspection, health surveillance, milk pasteurization or human BCG vaccination, transmission to humans still occur and is considered a public health risk. However, nowadays BTb control is more concerned with trade implications(1). According to official data, BTb in Portugal increased from 0.22 to $0.91 \%$ and from 0.07 to $0.26 \%$ for an animal and household prevalence respectively between 2005 and 2010(11). Control of BTb in Portugal is mandatory, based on test-andslaughter program(12) and movement restriction of positive herds. However, the increase in both animal and household prevalence show the need of develop new strategies, in addition of sanitary measures, where training/education of cattle producers may be fundamental to improve the national eradication program to achieve the reduction of its prevalence and further eradication of BTb. The livestock producer organizations played an essential role in the application and execution of BTb national eradication plans and education of farmers. Although the cases of human tuberculosis in the Northeast of Portugal decreased in the last years(13), no relationship was found between human tuberculosis among cattle producers(14).

According to the results of our study, almost three-quarters of respondents aged over 51 and presented low education/training. These results were not influenced the knowledge of the most important characteristics of BTb like clinical sings, routes of transmission or its zoonotical importance.

Transmission of BTb between animals is normally associated by inhalation of contaminated aerosol(1). Thus, $77.9 \%$ of respondents answered cattle-to-cattle transmission and the $76.1 \%$ of respondent recognized the aerogenic as the main route of transmission that affects the lungs primarily(15). 
explicación de este resultado no es fácil, el conocimiento de la infección a través de la leche puede estar asociado a la práctica de hervir la leche para evitar la infeccion por brucelosis(17). Además, la transmisión vertical de la TBb es infrecuente en áreas donde son ejecutados programas de erradicación(18).

Asociado al amplio rango de hospedadores que presenta M. bovis, su presencia en la fauna salvaje ha sido ampliamente descrita $(19,20,21)$. La implicación de la fauna en el ciclo natural del patógeno implica un obstáculo en la erradicación de la TBb en lugares donde la fauna salvaje y el ganado bovino comparten la misma área(22).

Este hecho se refleja en nuestro estudio, donde casi la mitad de los ganaderos considera que los venados y los jabalies pueden actuar como fuente de infección $(19,23)$, probablemente asociado a la zona montañosa donde se realizó el estudio, así como por el manejo semi extensivo o extensivo del ganado, donde existen áreas comunes de fauna salvaje y ganado(24).

En Portugal, debido a la existencia de datos epidemiológicos en los que la fauna salvaje actúa como reservatorio de la TBb, ha llevado a las autoridades a la elaboración de legislación específica sobre la caza(25). La autorización previa por parte de la autoridad nacional veterinaria así como la presencia de un veterinario oficial inspector sanitario, para realizar la inspección de las piezas de caza, son medidas preventivas para evitar posibles casos de infecciones de carácter zoonótico. Sin embargo, el hecho de que el $45.5 \%$ de los ganaderos desconoce el papel de la fauna salvaje como reservorio de BTb, hace necesaria la elaboración de programas de formación complementarios al plano nacional de erradicación de la BTb con el objetivo de controlar su prevalencia.

La sintomatología clínica de la TBb es inespecífica. Los bovinos afectados presentan generalmente una pérdida progresiva en su
Although contamination of cattle via the gastrointestinal tract is considered as a secondary route(16), the study showed that farmer had good knowledge of this route. Indeed, $62.3 \%$ and $73.4 \%$ of respondent recognized grazing and milking as routes of infection respectively. While the explanation for this result is not easy, the knowledge of transmission through milk could be associated to the general practices of heat-treated milk consume to avoid brucellosis(17). Nevertheless, vertical transmission is uncommon in areas where compulsory eradication programmes plans operate(18).

Associated to the extensively host range of $\mathrm{M}$. bovis, its presence in wildlife has largely described $(19,20,21)$. The implication of the wildlife in the natural cycle of the pathogen implies an obstacle to BTb eradication in landscapes where wildlife and cattle reared in coexistence(22). This fact was reflected in our study where just over half $(54.5 \%)$ of respondent considered wild boars or deer as a source of infection $(19,23)$; probably associated to the mountainous area of the study, to the extensive or semi-intensive cattle management resulting in overlapping ranges between wildlife and cattle(24) and the farmers' concern due to the direct threatened with the disease. In addition, an association between wildlife contact and BTb transmission $(P<0.001)$ was found.

In Portugal, the recognition of wildlife, as a reservoir of BTb and as a potential public health risk, has determined the elaboration of specific legislation to game meat control(25). Measures like previously authorization of hunt activities and presence of an authorized veterinary is compulsory to perform the meat inspection to avoid zoonotical infections. However, the fact that $45.5 \%$ of respondent unknown the importance of wildlife as a BTb source implies the need of training/education of cattle producers to control its prevalence as a complementary issue of the national BTb eradication program.

Clinical signs of BTb are non-specific and infected animals usually presented a gradually 
condición corporal hasta que son eliminados por su improductividad(26). Contrariamente, el $45.5 \%$ de los ganaderos cree que la TBb es una enfermedad aguda, siendo que el $60 \%$ de ellos cree que la sintomatología en bovinos infectados es evidente.

La producción bovina del área en estudio es principalmente cárnica, por lo que los problemas respiratorios son los más importantes desde el punto de vista sanitario(27). En consecuencia, la asociación entre los problemas respiratrorios y la tuberculosis puede explicar estos resultados, aunque la baja prevalencia de la TBb en el área de estudio es incompatible con estos resultados(28). Todavía, la falta de asistencia veterinaria en las explotaciones ganaderas de tipo familiar aumenta el desconocimiento de los síntomas clínicos.

En Portugal, el diagnóstico de la TBb en las explotaciones ganderas es efectuado mediante la prueba de intradermotuberculinización comparada en las campañas de saneamiento y en los test premovimiento de acuerdo con la legislacion vigente(29). El $75 \%$ de los ganaderos reconoce la finalidad de esta prueba. Además, el 72.7 y el $37 \%$ reconocen que el diagnóstico de la TBb tambien puede ser efectuado por medio de análisis sanguíneo y en la inspección sanitaria de los mataderos, respectivamente.

Aunque el programa oficial de erradicación contempla la utilización de la prueba del interferón gamma en casos específicos, estos resultados no son consistentes con la escasa utilización de esta prueba en todo el País, especialmente, en el área en estudio durante el periodo en estudio(28).

Por el contrario, el diagnóstico de la brucelosis bovina y de la leucosis enzoótica bovina mediante el análisis sanguineo durante las campañas oficiales puede explicar esta relación $(30,31)$, ya que ambas enfermedades son rastreadas simultáneamente.

Además, el estudio muestra que aquellos ganaderos que consideraron que el diagnóstico decline in body condition until they are culled for being non-productive(26). However $45.5 \%$ of respondent considered BTb as a acute disease and $60 \%$ of them consider that evident clinical signs was presented in cattle. The main animal production of the study area was beef and respiratory problems are usually the principal sanitary issue of these herds(27). In consequence, the association between respiratory diseases and tuberculosis by cattle producers may explain these results. In addition, the low prevalence of BTb in the area of study is also incompatible with these results(28). Furthermore, the lack of veterinary assistance on these family managed farms of the study enhances the misunderstanding of clinical signs.

In Portugal, BTb diagnosis at farm level is carried throughout the single intradermal cervical comparative tuberculin (SICCT) test during campaign and pre-movement test according to official guidelines(29). Thus, almost threequarters of respondent recognized this test and its objective. Blood sample and meat inspection at slaughterhouse were considered also for BTb diagnostic by $72.7 \%$ and $37 \%$. Although national eradication program considers the utilization of gamma interferon assay in particular cases, this result is not consistent with the low level of utilization in the whole country and, specially, with the absence of utilization in the area of study(28). In contrast, the result of BTb diagnostic by blood sample may be explained due to the association of blood sample collection for bovine brucellosis and enzootic bovine leukosis screening $(30,31)$, during the official campaign by cattle producers because the screening of the three diseases was taken in place simultaneously. The study also revealed that knowledge tuberculosis diagnostic by blood sample is influenced in case family or friend infected $(P<0.05)$, may be associated to the lack of knowledge of respondent on the tuberculin skin test existence for human tuberculosis detection(32) as well as the beliefs that test in animals are not applicable in to human. Lesion detection during meat inspection at slaughterhouse represents 
de la tuberculosis por medio del análisis sanguíneo está influenciado en los casos en los que existen familiares y amigos infectados $(P<0.05)$ ya sea por el desconocimiento de los propios ganaderos de la existencia de la prueba de intradermotuberculinización para personas(32) o por creer que las pruebas aplicadas en animales no son aplicables en personas.

La detección de lesiones características en el matadero durante de la inspección sanitaria, representa una importante medida de control pasivo en áreas con baja prevalencia de TBb, que complementa el diagnóstico in vivo(33). El escaso conocimiento de la detección de la TBb en mataderos está de acuerdo con el tipo productivo de la zona objeto de estudio, donde los bovinos son enviados para sacrificio con cerca de un año de edad. Así, dado el carácter crónico de la TBb hace que el decomiso total de la canal por esta causa, en el matadero, sea poco frecuente

El control de la TBb en las explotaciones ganaderas require la aplicación de medidas de bioseguridad, por lo que la formación del ganadero es fundamental. La bioseguridad se define como el conjunto de medidas llevadas a cabo para evitar el contagio de enfermedades de poblaciones, explotaciones o animales donde no existen, o para limitar la expansión de una enfermedad en una explotación(34). Entre estas medidas, el control de la movilización del ganado, cumplimiento de la legislación relativa a la TBb y la aplicación de buenas prácticas ganaderas son esenciales para su control.

Dado que los ganaderos reconocen correctamente la trasmisión de la TBb por vía aerógena, el $74 \%$ de ellos considera necesario aislar los bovinos positivos del resto del hato. La movilización del ganado está controlada por la autoridad veterinaria nacional, siendo ésta restricta en caso de hatos positivos. Esta restricción es reconocida por el $75.3 \%$ de los ganaderos.

La movilización del ganado es considerada como un posible factor de riesgo de infeccion por important passive surveillance of BTb in areas of low prevalence to supplement live cattle testing(33). The low knowledge showed by respondent is according main animal production of the study area and its low animal and household prevalence. Animals sent to slaughterhouse averaged one year old and due to chronic characteristics of BTb made that carcass, rejection by this disease is unusual.

Control of BTb in herd needs the application of biosecurity plan and consequently, farmer training is fundamental. Biosecurity refers to those measures taken to keep diseases out of populations, herds, or groups of animals where they do not currently exist or to limit the spread of disease within the herd(34). Among these measures, control of animal movement, fulfilment of BTb policy and good farm practices are essential to its control.

Due to the good knowledge of BTb airborne transmission showed by respondent, as seen before, $74 \%$ considered necessary the isolation of tuberculosis positive cattle.

Cattle trade/movement is controlled by the veterinary official services, and restricted in tuberculosis positive herds. This constraint was recognized by $75.3 \%$ of respondents. Cattle movement/trade is recognized as a BTb risk factor(35). Thus, in Portugal, all cattle movements from farm-to-farm and farm-toslaughterhouse have been accompanied with an official cattle movement form that is compulsory registered in the national cattle database (SNIRA)(36). Moreover, the sanitary status regarding BTb and brucellosis (free or non-free) is also registered in the National health animal database (PISA.net). In case of positive herds, farmers must provided all the cattle identification documents to the regional veterinary authorities and must to sign an official form where they are informed that cattle trade from farm-to-farm is forbidden. Thus, movement restriction is registered both in SNIRA and PISA.net. In case of movement/trade of infected cattle, the compulsory record of the movement 
$\mathrm{TBb}(35)$, por lo que en Portugal, todos los movimientos del ganado bovino entre explotaciones ganaderas y de éstas para los mataderos deben ser acompañadas de guías oficiales, siendo éstas registrados en el sistema nacional de indentificación y registro animal (SNIRA) (36).

Además, el estatuto sanitario relacionado con la TBb y la brucelosis bovina (indemne o no indemne) es registrado en el programa informático nacional de sanidad animal (PISA.net).

En en caso de hatos positivos, los ganaderos deben entregar todos los documentos identificativos de los bovinos a la autoridad veterinaria local, así como firmar un documento en el que son informados de la prohibición de cualquier movilización de ganado entre explotaciones ganaderas. Esta prohibición es también registrada en el SNIRA y en el PISA.net. En caso de una posible movilización de un bovino perteneciente a un hato positivo, el registro de la correspondiente guía de movilización en el SNIRA es impedido, alertando a las autoridades veterinarias de dicha situación.

Para aumentar la seguridad sanitaria en el comercio de bovinos, aquéllos que tienen como mínimo un año de edad, deben ser sujetos a un test premovimiento antes de abandonar la explotación de origen. Aunque esta prueba conlleva un gasto económico para los ganaderos y su eficacia real como medida complementaria a las campañas de saneamiento de la TBb no está totalmente comprobada(37), su aplicación es una garantía tanto del estado sanitario, como de las relaciones comerciales. Además, las pérdidas económicas asociadas a la restricción de movimientos en caso de bovinos positivos, son mucho mayores que el propio costo del test premovimiento.

En paises desarrollados, el objetivo principal del control de la TBb es garantizar el comercio del ganado, siendo este aspecto bien reconocido por los ganaderos, ya que el $64.3 \%$ reconoce form in the SNIRA database is not possible and an alert is set.

To increase the safety of cattle trade, a premovement test is compulsory in cattle over 1 year prior they leave the farm to another farm. Although this test is an economical constrain for farmers and its effectiveness as a complementary measure to national erradication program is not enterely clear(37), its application is an asset to guarantee the sanitary status and the commercial relationships for livestock trade. Moreover, the economic losses due to movement restriction in infected herds are higher than pre-movement cost itself.

In industrialized countries, the main objective of BTb control, as described above, is to ensure the cattle trade and this aspect is well known by farmers where $64.3 \%$ knows that livestock commerce is a risk of BTb. Consequently, the study revealed that $70.8 \%$ of respondents agree to the compulsory of the premovement(38). In addition, the use of loaned bulls without pre-movement test was recognized by $68.8 \%$ of respondent as a risk factor of $\mathrm{BTb}(39)$.

BTb is also been influenced by herd management factors like herd size, historical prevalence of BTb on the area, housing or farming system among others $(40)$. The more cattle there are on a farm, the greater the probability of BTb infection. This aspect is associated to the herd density and the increase of cattle-to-cattle spread risk ${ }^{(41)}$ and the more intensive production system, the more levels of animal stress and BTb susceptibility. The fact that almost $60 \%$ of farm of our study presented three or less head may be interpreted as a protective factor, although no statistical differences were verified in the herd size as contrary described by several authors $(42,43)$. The semi-extensive production of most of them may also be a protective factor due to the low animal stress as contrary as published in other study(44) where cubicle housing characteristic of intensive dairy farm is more stressful for cattle and 
que el comercio de ganado es un factor de riesgo. El estudio también reveló que $70.8 \%$ de los ganaderos está de acuerdo con la realización de los test pre-movilización(38) mientras que un $68.8 \%$ de los mismos reconoce que la utilización de toros para monta natural sin test pre-movilización es un riesgo de infeccion de $\mathrm{TBb}(39)$.

La TBb también está influenciada por el tipo de manejo de la explotación, como por ejemplo el tamaño del hato bovino, prevalencia en la zona, o instalaciones entre otros(40). Entre mayor el número de bovinos, mayor es la probabilidad de infección. Este aspecto está asociado con la densidad animal, que conlleva a un aumento del contacto entre animales(41) y a la intensificación de la producción, lo que provoca un aumento del estrés de los animales y, consecuentemente, la susceptibilidad a la TBb.

El hecho de que casi el $60 \%$ de las explotaciones del estudio presentaban tres o menos cabezas puede ser interpretado como un factor de protección, aunque no se observaron diferencias significativas según el tamaño del rebaño, al contrario de los descrito por otros autores $(42,43)$. La producción semi-extensiva de la mayoría de las explotaciones ganaderas también puede considerarse como um factor de protección debido al bajo nivel de estrés de los bovinos, al contrario de lo publicado en otro estudio(44) donde el alojamiento en cubículos en explotaciones lecheras es causa de un aumento del estrés, lo que contribuye para aumentar la subceptibilidad a la TBb. Además, este autor considera que el manejo del estiercol también es un factor de riesgo para la $\mathrm{TBb}$, ya que su utilización como abono para los pastos, sin tratamiento previo, aumenta el riesgo de infección, tanto por vía aerógena como por vía digestiva; si bien, los bovinos necesitan ingerir mayores dosis de $M$. bovis que las necesarias por via aerógena(44) para resultar infectados. Dado que en el área en estudio, la utilización del estiércol como abono se realiza una vez por año, $80 \%$ de los ganaderos tratan el estiércol antes de ser utilizado como abono. contribute to increase the susceptibility to BTb. Moreover, this author considers the manure management as a risk factor of BTb because the spreading of slurry on pasture without prior storage increase the risk of infection, both airborne and digestive route due to the inhalation of aerosol during the spreading or grazing respectively. Nevertheless, cattle need to ingest much higher doses of $M$. bovis than to the aerogenic transmission(44). Due to the spreading of slurry, once a year is a general practice on the study area; almost $80 \%$ of respondent declared to treat the manure prior to spreading. Feeding management revealed that $64.9 \%$ of respondent considered untreated water and improper feed storage a risk to BTb. In the case of feed, this answer may be associated to the providing hay bales in the ground instead of feeders (45); although possible contamination of bales by wildlife could be another explanation due to the well knowledge of respondent about this issue as seen before.

In the other hand, $27.9 \%$ of respondent not recognized BTb as one of the most important disease of cattle due to the economical losses and trade restrictions, $25 \%$ of them not recognized the primary transmission of Btb through the exchange of respiratory secretions between infected and uninfected animals and $46.7 \%$ unknown wildlife as a reservoir of bovine tuberculosis. Furthermore, $40.9 \%$ of respondent considered BTb as an acute disease with evident clinical signs. Although control of BTb in mandatory and cattle positive to the intradermal test (IDT) is culled, $49.4 \%$ considered BTb as a treatable infectious disease when it is strictly prohibited by law(46). These results may be explained by the absence of a veterinarian in the farm $(60.4 \%)$ which is only requested in case of sick cattle by $69.5 \%$ of respondent. It can be concluded that the role of the veterinarian in the education/training of cattle producers is essential to improve the understanding of Btb an also other aspect like farm biosecurity, veterinary legal fulfillment and veterinary public health(46). 
En relación a la alimentación del ganado, $64.9 \%$ de los ganaderos respondieron que la utilización de agua no tratada o alimentos almacenados incorrectamente pueden constituir un riesgo de TBb. En el caso de la alimentación, esta respuesta puede estar relacionada por la distribución de rollos de hierba/forraje por el suelo en vez de colocarlos en los comederos(45), aunque la contaminación de los mismos por la fauna salvaje puede ser otra explicación, debido al conocimiento de los ganaderos a este asunto.

Por otro lado, el $27.9 \%$ de los ganaderos desconoce que la TBb es una de las enfermedades más importantes de los bovinos debido a las consecuencias económicas asociadas a las restricciones comerciales, $25 \%$ de ellos no reconoce la transmisión de la enfermedad por vía aerógena y el $46.7 \%$ desconoce la importancia de la fauna salvaje como reservatorio de TBb.

El $40.9 \%$ de los ganaderos consideró que la $\mathrm{TBb}$ es una enfermedad aguda con sintomatologia clínica evidente. Aunque el diagnóstico de la TBb es obligatorio y todos los bovinos positivos a la prueba de la intradermotuberculinización son sacrificados, $49.4 \%$ de los ganaderos encuestados consideraron que la TBb es una enfermedad tratable, aún cuando esta situación es estrictamente prohibida por ley(46). Estos resultados pueden ser explicados por la falta de veterinarios en las explotaciones $(60.4 \%)$, el cual sólo es solicitado por el $69.5 \%$ de los ganaderos en caso de existir bovinos enfermos. Se puede concluir que el papel del veterinario es fundamental en la formación de los ganaderos para incrementar el conocimiento tanto sobre la TBb como sobre bioseguridad, aspectos legales veterinarios y sobre aspectos de salud pública veterinaria(46).

Para obtener todavia mejores resultados, la colaboración con profesionales médicos y de otras áreas de la salud pública puede ser importante.
To achieve better results, collaboration with human public health personnel may be also important.

\section{CONCLUSIONS AND IMPLICATIONS}

In this study we assessed the knowledge of cattle owners' about bovine tuberculosis in Portugal. The study has revealed low levels of knowledge among cattle owners on BTb and on biosecurity measures. These results could be useful for policy makers when planning BTb eradication programs to consider knowledge levels by cattle owners for effective implementation. Such information is useful for determining sensitization programs for cattle owners before eradication. These results further provide useful insights that disease control is a multi factorial process with cattle owners as an integral part that can support policy implementation

\section{ACKNOWLEDGEMENTS}

The authors thank all cattle producers to their disinteresting collaboration.

The work was supported by the strategic research project PEst-OE/AGR/UI0772/2011 financed by the Foundation for Science and Technology (FCT).

End of english version

\section{CONCLUSIONES E IMPLICACIONES}

El estudio reveló que los ganderos poseen un bajo conocimiento no sólo de la TBb, como sobre medidas de bioseguridad. Los resultados obtenidos pueden ser de gran utilidad para las autoridades veterinarias en la planificación de los programas de erradicación de la TBb. Estos resultados son interesantes para la elaboración de programas de sensibilización para los 
ganaderos, antes de la aplicación de los programas de erradicación. Ademas, los resultados de este estudio muestran que el control de esta enfermedad es de carácter multifactorial, donde los propios ganaderos son una parte fundamental para su control.

\section{AGRADECIMIENTOS}

Los autores agradecen a todos los ganaderos que participaron en este trabajo de forma desinteresada. Este trabajo fue realizado a través del proyecto de investigación Pest-OE/AGR/ UI 0772/2011 financiado por la Fundação para a Ciência e Tecnologia (FCT).

\section{LITERATURA CITADA}

1. Skuce RA, Allen AR, McDowell WJ M. Herd-Level risk factors for bovine Tuberculosis: A literature review. Vet Med Int 2012; 12: 1-10.

2. Rodriguez-Campos $S$, Schürch $A C$, Dale J, Lohan AJ, Cunha MV, Botelho A, et al. European 2-a clonal complex of Mycobacterium bovis dominant in the Iberian Peninsula. Infect Genet Evol 2012;12:866-872.

3. Ward Al, Judge J, Delahay RJ. Farm husbandry and badger behaviour: opportunities to manage badger to cattle transmission of Mycobacterium bovis? Prev Vet Med 2010; 93:2-10.

4. Schwabe CW. Veterinary medicine and human health. Baltimore, USA: Williams \& Wilkins; 1984.

5. Munyeme M, Muma J B, Hetron M, Munangandu HM, Kankya C, Skjerve E, et al. Cattle owners' awareness of bovine tuberculosis in high and low prevalence settings of the wildlife-livestock interface areas in Zambia. BMC Vet Res 2010; 6:21.

6. Cosivi O, Grange JM, Daborn CJ, Raviglione MC, Fujikura T, Cousins D, et al. Zoonotic tuberculosis due to Mycobacterium bovis in developing countries. Emerg Infect Dis 1998; 4:5970.

7. Torres-Gonzales P, Soberanis-Ramos O, Martínez-Gamboa A, Chavez-Mazari B, Barrios-Herrera MT, Torres-Rojas M, Cruz-Hervert LP, et al. Prevalence of latent and active tuberculosis among dairy farm workers exposed to cattle infected by Mycobacterium bovis. PLOS Neglected Trop Diseases 2013;4; e2177.

8. Rua-Domenech R. Human Mycobacterium bovis infection in the United Kingdom: incidence, risk, control measures and review of the zoonotic aspects of bovine tuberculosis. Tuberculosis 2006; 86:77-109.
9. Winthrop KL, Scott J, Browm D, Jay MT, Rios R, Mase S, et al. Investigation of human contacts: a Mycobacterium bovis outbreak among cattle at California dairy. Int J Tuber Lung Dis 2005; 9:809-813.

10. Michel AL, Muller B, van Helden PD. Mycobacterium bovis at the animal-human interface: A problem or not? Vet Microbiol 2010; 140:371-381.

11. DGV. Direcção Geral de Veterinária. Portugal. Programa de erradicação da brucelose dos bovinos em Portugal - 2012. Ministério de Agricultura, Mar, Ambiente e Ordenamento do Território. Lisboa. Portugal. 2011.

12. Portugal 272/2000. Decreto-Lei n.ㅇ 272/2000 que adopta medidas de combate à tuberculose bovina e altera as normas relativas à classificação sanitária dos efectivos bovinos. Portugal. 2000.

13. DGS. Direcção Geral de Saúde. Portugal. Elementos estatísticos - informação geral - saúde - 2008. Portugal. 2010.

14. Vilhena MJ. Identificação das zonas de risco para a tuberculose zoonótica em Portugal [MSc dissertation]. Portugal: University of Porto; 2011.

15. Kaneene JB, Pfeiffer D. Epidemiology of Mycobacterium bovis. In: Thoen CO, Steele JH, Gilsdorf MJ editors. Mycobacterium bovis infection in animals and humans. Iowa, USA: Blackwell; 2006: 34-48.

16. Menzies FD, Neill SD Cattle-to-cattle transmission of bovine tuberculosis. Vet J 2000; 160:92-106.

17. Serra J, Pujol R, Godoy P. Seroepidemiological study of brucellosis in a rural endemic area. Enferm Infec Micr Cl 2000; 18: 74-78.

18. Neill SD, Pollock JM, Brysson DB, Hanna J. Pathogenesis of Mycobacterium bovis in cattle. Vet Microbiol 1994;40:4152.

19. Cunha MV, Matos F, Canto A, Albuquerque T, Alberto JR, Aranha J M, et al. Implications and challenges of tuberculosis in wildlife ungulates in Portugal: A molecular epidemiology perspective. Res Vet Sci 2012; 92:225-235.

20. Johnson LK, Liebana E, Nunez A, Spencer Y, Clifton-Hadley $R$, Jahans $K$, et al. Histological observations of bovine tuberculosis in lung and lymph node tissues from British deer. Vet J 2008; 175:409-412.

21. Simpson VR. Wild animals as reservoirs of infectious diseases in the UK. Vet J 2002;163:128-146.

22. Naranjo V, Gortazar C, Vicente J, Fuente J. Evidence of the role of European wild boar as a reservoir of Mycobacterium tuberculosis complex. Vet Microbiol 2008;127:1-9.

23. Brook RK, McLachlan SM. Factors influencing farmers' concerns regarding bovine tuberculosis in wildlife and livestock around Riding Mountain National Park. J Environ Management 2006; 80:156-166.

24. Stronen AV, Brook RK, Paquet PC, Mclachlan S. Farmer attitudes toward wolves: Implications for the role of predators in managing disease. Biol Conserv 2007;135:110.

25. DGV. Direcção Geral de Veterinária. Portugal. Edital N.ㅇ 1. Tuberculose em caça maior. Portugal. 2011.

26. Collins MT. Infectious diseases: tuberculosis. In: Fuquay JW, McSeeney PLH editors. Encyclopedia of dairy Sciences Academic Press, London, United Kingdom; 2011:195-198. 
27. Callan RJ, Garry FB. Biosecurity and bovine respiratory disease. Vet Clin N Am-Food A 2002; 18:57-77.

28. DGV. Direcção Geral de Veterinária. Portugal. Relatório técnico de tuberculose dos bovinos. Portugal. 2012.

29. Portugal $157 / 98$. Decreto-Lei $157 / 98$ de 9 de Junho que estabelece a disciplina das trocas intracomunitárias de animais das espécies bovina e suína. Portugal. 1998.

30. DGAV. Direcção Geral de Alimentação e Veterinária. Portugal. Programa de erradicação plurianual da leucose enzoótica bovina (LEB). Divisão de Intervenção Veterinária do Porto. Portugal. 2012.

31. DGV. Direcção Geral de Veterinária. Portugal. Programa de erradicação da brucelose dos bovinos em Portugal - 2012. Ministério de Agricultura, Mar, Ambiente e Ordenamento do Território. Lisboa. Portugal. 2011.

32. Britton WJ, Gilbert GL, Wheatley JM, Leslie D, Rothel J S, J ones SL et al. Sensitivity of human gamma interferon assay and tuberculin skin testing for detecting infection with Mycobacterium tuberculosis in patients with culture positive tuberculosis. Tuberculosis 2005; 85:137-145.

33. Schiller I, RayWaters W, Vordermeier HM, Jemmi T, Welsh $M$, Keck $N$, et al. Bovine tuberculosis in Europe from the perspective of an officially tuberculosis free country: Trade, surveillance and diagnostics. Vet Microbiol 2011;151:153159.

34. Dargatz DA, Garry FB, Traub-Dargatz JL. An introduction to biosecurity of cattle operations. Vet Clin N Am-Food A 2002; 18: 1-5.

35. Ramírez-Villaescusa AM, Medley GF, Mason S, Green LE. Herd and individual risk associated with bovine tuberculosis skin test positivity in cattle in herds in Southwest England. Prev Vet Med 2009; 92: 188-198.

36. Portugal 142/2006. Decreto-Lei 142/2006 de 27 de Junho que cria o Sistema Nacional de Informação e Registo Anima (SNIRA) e as regras de identificação e circulação dos animais das espécies bovina, ovina, caprina, suína bem como dos equídeos. Portugal. 2006.

37. Clegg TA, More SJ, Higgins IM, Good M, Blake M, Williams $\mathrm{DH}$. Potential infection-control benefit for Ireland from pre- movement testing of cattle for tuberculosis. Prev Vet Med 2008; 84:94-111.

38. Christley RM, Robinson SE, Moore B, Setzkorn C, Donald I. Responses of farmers to introduction in England and Wales of pre-movement testing for bovine tuberculosis. Prev Vet Med 2011;100: 126-133.

39. Kaneene JB, Brunning-Fann CS, Granger LM, Miller R, PorterSpalding BA. Environmental and farm management factors associated with tuberculosis on cattle farms in North-eastern Michigan. J Am Vet Med Assoc 2002;221:837-842.

40. Humblet MF, Boschiroli ML, Saegerman C. Classification of wordwide bovine tuberculosis risk factors in cattle: a stratified approach. J Vet Res 2009;50:1-17.

41. Rua-Domenech R, Goodchild AT, Vordermeier HM, Hewinson RG, Christiansen KH, Clifton-Hadley RS. Ante mortem diagnosis of tuberculosis in cattle: a review of the tuberculin tests, c-interferon assay and other ancillary diagnostic techniques. Res Vet Sci 2006; 81: 190-210.

42. Griffin J M, Martin SW, Thorburn MA, Eves JA, Hammond RF. A case-control study on the association of selected risk factors with the occurrence of bovine tuberculosis in the Republic of Ireland. Prev Vet Med 1996;27:75-87.

43. Munroe FA, Dohoo IR, McNab WB, Spangler L. Risk factors for the between-herd spread of Mycobacterium bovis in Canadian cattle and cervids between 1985 and 1994. Prev Vet Med 1999;41:119-133.

44. Griffin J M, Hahesy T, Lynch K, Salman MD. The association of cattle husbandry characteristics, environmental factors and farmer characteristics with the occurrence of chronic bovine tuberculosis in dairy herds in the Republic of Ireland. Prev Vet Med 1993;17:145-160.

45. Morris RS, Pfeifer DU, Jackson R. The epidemiology of Mycobacterium bovis infections. Vet Microbiol 1994;40:53177.

46. Portugal 244/2000. Decreto-Lei n. 0 244/2000 de 27 de Setembro. Portugal. 2000.

47. Cripps PJ. Veterinary education, zoonoses and public health: a personal perspective. Acta Trópica 2000;76:77-80. 
